\title{
Pemberdayaan Kelompok Nelayan Desa Bandengan Jepara Melalui Pengolahan Hasil Laut
}

\author{
Mariana Kristiyanti \\ STIMART “AMNI” Semarang \\ email : mkristiyanti75@gmail.com \\ Siswadi \\ STIMART “AMNI” Semarang \\ siswadi_59@stimart-amni.ac.id
}

\begin{abstract}
Bandengan are the village in addition to north of Jepara, where the majority people are fishermen fullfil life need to find fish in the sea.By being a fisherman, the rural communities Bandengan Jepara do not have skill other than look for fish. When fish catch up, so the sale of fish rose, but it was with increasing fish catch will not only fisher incomes are rising, but also the problems increasing fish catch not sold out.The majority of fishermen throw the catch the fish not salable sold. This is because fish decaying, although it is stored in cool box. For that the implementation team devotion the STIMART "AMNI" Semarang, an initiative to give management skills fish catch instant for products to minimize loss caused by membusuknya fish not salable sold. Some of these programs developed for fishing groups bandengan village in anticipation of the problem.Including by giving skills make "nuggets" of fish at once a method omnipresence through the online system. A special purpose is to be achieved in the community devotion this is given the faculty fishing groups to be able to offer the fish not actually sold, instant for products and marketing it through some media based on line.
\end{abstract}

Keywords: fishing communities, bandengan village, process fisheries products, ready to eat products

\begin{abstract}
Abstrak
Desa Bandengan merupakan desa yang berada di samping utara kota Jepara, dimana mayoritas penduduknya adalah nelayan yang memenuhi kebutuhan hidupnya dengan mencari ikan di laut. Dengan menjadi seorang nelayan, masyarakat di desa Bandengan Jepara tidak memiliki keahlian lain selain mencari ikan. Pada saat hasil tangkapan ikan meningkat, maka hasil penjualan ikan juga meningkat, tetapi ternyata dengan meningkatnya hasil tangkapan ikan maka tidak hanya pendapatan nelayan saja yang meningkat, tetapi juga adanya permasalahan mengenai meningkatnya hasil tangkapan ikan yang tidak habis terjual. Mayoritas nelayan membuang hasil tangkapan ikannya yang tidak laku terjual. Hal ini dikarenakan ikan membusuk, walaupun sudah di disimpan dalam cool box. Untuk itu tim pelaksana kegiatan Pengabdian Masyarakat STIMART "AMNI" Semarang, berinisiatif memberikan ketrampilan pengolahan hasil tangkapan ikan menjadi produk siap saji untuk meminimalkan kerugian yang diakibatkan oleh membusuknya ikan yang tidak laku terjual. Beberapa program telah disusun untuk kelompok nelayan desa Bandengan dalam mengantisipasi permasalahannya. Diantaranya adalah dengan memberikan ketrampilan membuat 'nugget' dari ikan sekaligus metode pemasarannya melalui media on line system. Tujuan khusus yang ingin dicapai pada program Pengabdian Masyarakat ini adalah memberikan kemampuan kelompok nelayan agar mampu mengolah hasil ikan yang tidak terjual, menjadi produk siap saji dan dapat memasarkannya melalui berbagai media berbasis On Line.
\end{abstract}

Kata Kunci : Kelompok Nelayan, Desa Bandengan, Pengolahan Hasil Laut, Produk Siap Saji 


\section{PENDAHULUAN}

Desa Bandengan, merupakan desa yang berada di pesisir pantai kota Jepara. Pantai yang ada di desa Bandengan, lebih di kenal dengan nama pantai Prawehan yang merupakan sumber mata pencaharian utama masyarakat di sekitar desa Bandengan Jepara. Berdasarkan letak geografis, bagian Desa Bandengan berada di samping utara ibu kota Kabupaten Jepara. Desa Bandengan merupakan salah satu Desa di Kecamatan Jepara, dengan jarak tempuh ke ibu kota kecamatan $7 \mathrm{~km}$ dan ke ibukota kabupaten $7 \mathrm{~km}$ serta dapat ditempuh dengan kendaraan kurang lebih 15 menit. Desa ini berbatasan dengan desa Wedungcino dan desa Mororejo di samping utara, desa Kuwasen dan desa Mulyoharjo di samping selatan, desa Wonorejo di samping timur dan Laut Jawa di samping barat. Luas wilayah daratan Desa Bandengan adalah $586.449 \mathrm{~km}^{2}$ dengan panjang pantai $5 \mathrm{~km}$.

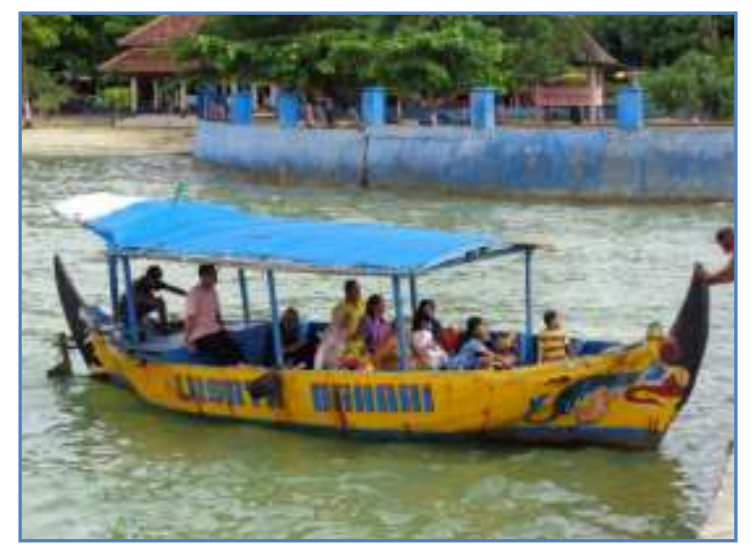

\section{Gambar 1. Pantai Prawehan, Desa Bandengan Jepara}

Masyarakat desa Bandengan mayoritas penduduknya memiliki mata pencaharian sebagai seorang nelayan. Dimana kesehariannya beraktifitas di lautan untuk mencari ikan. Masyarakat Bandengan tidak memiliki keahlian lain selain sebagai seorang nelayan. Hal ini berakibat kurang baik manakala hasil tangkapan berkurang atau bahkan tidak mendapatkan ikan, maka para nelayan tidak mendapatkan penghasilan pada hari dimana para nelayan tidak mendapatkan hasil tangkapan ikan. Sehingga tim pelaksana kegiatan pengabdian masyarakat STIMART "AMNI" Semarang mencoba untuk membuat 
program pemberdayaan bagi kelompok nelayan di desa Bandengan, agar dapat tetap mendapatkan penghasilan meskipun hasil tangkapan ikan berkurang atau tidak sama sekali mendapatkan tangkapan ikan.

Dilain pihak, permasalahan lain yang muncul adalah bila hasil tangkapan ikan melimpah dan tidak semuanya dapat terjual di pasaran. Maka ikan yang tidak terjual di pasaran tersebut akan membusuk dan akhirnya dibuang sia-sia. Hal ini akan merugikan kelompok nelayan yang mengharapkan pendapatannya meningkat saat hasil tangkapan ikannya meningkat
Gambar 2. Nelayan

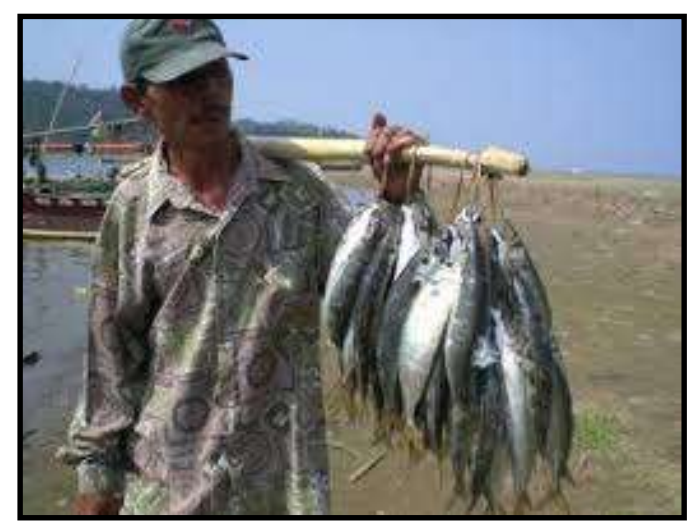

tangkapan ikan dengan hasil
Sebagai pantai yang merupakan tempat mencari pendapatan, pantai Prawehan sangat terawat kondisinya. Masyarakat desa Bandengan merawat daerah pantai Prawehan dengan baik, sehingga kondisinya sangat bersih dan indah. Hal ini sangat baik bagi masyarakat desa Bandengan, karena kondisi bersih dan indah memiliki daya tarik tersendiri bagi para wisatawan baik mancanegara maupun domestik untuk berkunjung. Sampai disini ternyata permasalahan kembali muncul untuk kelompok nelayan yang sering bertemu dan komunikasi dengan para wisatawan. Banyaknya kunjungan wisatawan asing ke pantai Prawehan Bandengan Jepara, membuat para nelayan merasa kesulitan dalam berkomunikasi dengan para wisatawan asing. Hal ini membuat kelompok nelayan yang ada di desa Bandengan harus bisa menguasai bahasa Inggris dengan baik agar dapat berkomunikasi dengan wisatawan asing. Tujuan khusus yang ingin dicapai pada program pelaksanaan kegiatan pengabdian masyarakat STIMART "AMNI" Semarang adalah :

1. Kelompok nelayan desa Bandengan Jepara dapat meningkatkan pendapatannya melalui peluang lain 
sebagai antisipasi apabila hasil tangkapan ikan tidak terlalu banyak,

2. Kelompok nelayan desa Bandengan Jepara dapat mengolah hasil tangkapan ikan yang tidak terjual di pasaran untuk diolah menjadi produk siap saji,

3. Kelompok nelayan desa Bandengan mampu berbahasa Inggris dengan baik, sehingga mampu berkomunikasi dengan para wisatawan asing,

4. Kelompok nelayan desa Bandengan Jepara dapat memasarkan produk hasil pengolahan ikan dengan media on line system.

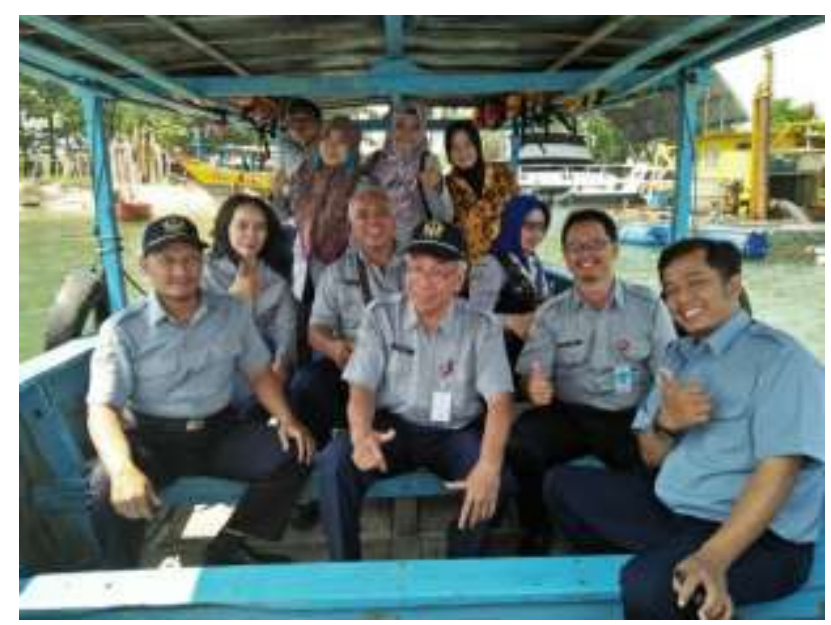

Gambar 3. Pantai Prawehan Bandengan Jepara yang bersih dan indah

Dengan berbagai alternatif kegiatan yang dapat dilakukan oleh nelayan dalam meningkatkan pendapatannya, diharapkan tingkat kesejahteraan kelompok nelayan desa Bandengan juga semakin membaik dan bahkan meningkat. Masyarakat desa Bandengan yang mayoritas nelayan, bila dapat meningkatkan kemampuan dalam berbahasa Inggris, maka akan mempermudah kelompok nelayan dalam berkomunikasi dengan para wisatawan asing, sehingga hal ini semakin mendekatkan diri antara para wisatawan asing dengan kelompok nelayan yang ada di desa Bandengan. Dan dengan demikian, diharapkan kelompok nelayan dapat lebih mengenalkan wisata pantai Prawehan yang berdampak pada peningkatan pengunjung wisatawan ke pantai Prawehan desa Bandengan Jepara.

Untuk mencapai tujuan-tujuan tersebut diatas, maka beberapa upaya telah dilakukan, diantaranya yaitu dengan menyelenggarakan pelatihan pengolahan hasil ikan menjadi prosuk jadi, metode pendekatan pembelajaran bahasa Inggris dengan konsep "Belajar sambil Bekerja" serta pelatihan memasarkan produk hasil 
olahan menjadi produk siap saji melalui media on line system.

\section{TINJAUAN PUSTAKA}

Mayoritas masyarakat pesisir pantai di Indonesia, khususnya masyarakat nelayan ternyata masih belum mendapatkan nilai lebih dari potensi kekayaan sumber daya laut yang ada di Indonesia. Masyarakat kelompok nelayan umumnya masih jauh dari sejahtera, hal ini ditunjukkan dengan tingkat pendidikan keluarga nelayan yang rendah dan tidak dapat memenuhi standar kesehatan maupun kebutuhan sehari-hari.

Menurut Mulyadi (2005) ada empat masalah pokok yang menjadi penyebab dari kemiskinan, yaitu kurangnya kesempatan (lack of opportunity), rendahnya kemampuan (low of capabilities), kurangnya jaminan (low level-security), dan keterbatasan hak-hak sosial, ekonomi, dan politik sehingga menyebabkan kerentanan (vulnerability), keterpurukan (voicelessness), dan ketidakberdayaan (powerlessness) dalam segala bidang.

Ketika pemerintah ingin menjadikan Indonesia sebagai Poros Maritim Dunia, namun masyarakat pesisir, khususnya masyarakat nelayan justru hanya menjadi penonton saja. Produksi hasil laut yang diperoleh nelayan sangatlah minim jika dibandingkan potensi sumber daya laut yang berada di lingkungan sekitar nelayan tersebut. Kebijakan tegas yang dilakukan Kementerian Kelautan dan Perikanan dalam menindak ilegal fishing dan kejahatan laut lainnya ternyata belum cukup untuk mengembalikan citra Indonesia sebagai masyarakat bahari dan maritim.

Kebijakan ini seharusnya dilanjutkan upaya dari pemerintah untuk meningkatkan daya saing masyarakat pesisir, khususnya nelayan sehingga pengelolaan wilayah pesisir dan laut dapat dilakukan bersama-sama.

Pariwisata merupakan sektor yang mempunyai potensi yang menjanjikan dalam bidang kesempatan kerja, kesempatan berusaha, serta kesempatan untuk dapat mengembangkan daerah, sehingga beberapa daerah menjadikan pariwisata sebagai program unggulan dalam pengembangan daerahnya.

Salah satu obyek wisata yang cukup digemari masyarakat adalah pantai. Pantai adalah sebuah bagian yang menjadi batas antara lautan dan daratan, bentuk pantai berbeda-beda sesuai dengan keadaan, proses yang terjadi di bagian tersebut, seperti pengangkutan, pengendapan dan pengikisan yang disebabkan oleh gelombang, arus, angin dan keadaan lingkungan disekitarnya yang berlangsung secara terus menerus, sehingga 
membentuk sebuah pantai (Nofia Farida, 2010)

Dalam bahasa Inggris pantai adalah coast yang menurut kamus Cambridge, coast bermakna the land next to or close to the sea artinya daratan yang berdekatan dengan laut. Sementara dalam kamus Bahasa Indonesia pantai artinya tepi laut atau pesisir. Dalam tataran praktis pantai bisa memiliki pengertian yang berbedabeda.

Sebagian berpendapat bahwa pantai adalah suatu daratan yang berbatasan langsung dengan laut menjorok ke dalam hingga pengaruh pasang surut air laut tidak terasa. Dengan definisi ini, lebar atau daerah pantai bisa berbeda-beda tiap daerah tergantung dari tinggi nya pasang surut di daerah tersebut. Untuk daerah landai dengan pasang surut yang tinggi, lebar pantai bisa puluhan kilometer.
Sebaliknya, untuk daerah yang curam atau bahkan pantai berbatu (cliff), daerah pantai mentok sampai pada ujung cliff tersebut.

Salah satu wisata pantai yang ada di kabupaten Jepara adalah pantai Prawehan yang berada di desa Bandengan. Di kawasan pantai Prawehan desa Bandengan ini tersedia berbagai fasilitas untuk para pengunjung agar merasa nyaman. Tersedia berbagai wahana bermain, restoran, tempat mandi atau bilas, penyewaan tikar, ban pelampung, kano, hingga wahana-wahana lainnya. Pantai Prawehan mempunyai pemandangan yang indah terutama pada sore hari ketika menjelang matahari terbenam. Pemandangan ini diperindah dengan tampaknya pulau Panjang dikejauhan pantai, sehingga layak jika pantai Prawehan dianggap mempunyai potensi wisata yang dapat meningkatkan ekonomi masyarakat di sekitar pantai.

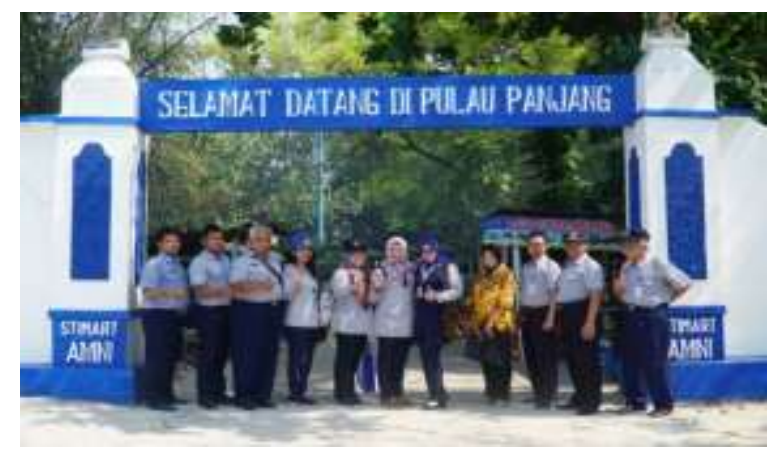

Gambar 4. Pulau Panjang Desa Bandengan Jepara

Wisatawan berkunjung ke pantai Prawehan, desa Bandengan dengan tujuan untuk menikmati keindahan pemandangan pantainya. Disamping itu karena dari pantai Prawehan desa Bandengan, wisatawan dapat langsung menuju ke 
pulau Panjang, yang jaraknya hanya sekitar setengah jam perjalanan, seperti dapat dilihat pada gambar 4 diatas, sehingga tidaklah berlebihan kiranya jika jumlah kunjungan ke pantai Prawehan desa Bandengan ini cenderung meningkat. Di lain pihak, pulau Panjang juga menjanjikan pemandangan alamnya juga tidak kalah indahnya dengan pantai Prawehan desa Bandengan.

Peningkatan pendapatan masyarakat kelompok nelayan, dikatakan meningkat apabila terjadi perubahan secara terus menerus (kontinue) dalam jangka panjang terhadap tingkat pemenuhan kebutuhan. Pemenuhan kebutuhan selalu dikaitkan dengan pendapatan atau harta yang dimilikinya, tinggi rendahnya pendapatan membawa dampak pada kondisi ekonomi dalam keluarga nelayan. Secara umum ada hubungan antara tingkat konsumsi dengan penerimaan (pendapatan). Peningkatan pendapatan akan membuat jumlah pemenuhan kebutuhan meningkat, sebaliknya penurunan pendapatan akan mengurangi jumlah kebutuhan yang ingin diperoleh. Apabila penurunan pendapatan tersebut terjadi terus menerus dalam jangka waktu yang panjang akan membawa akibat kemiskinan bagi masyarakat atau rumahtangga nelayan. Namun apabila penurunan jumlah pendapatan dapat segera diatasi dengan baik, kondisi ekonomi akan membaik pula.

Untuk mengatasi masalah ekonomi masyarakat kelompok nelayan tentunya tidak semudah seperti apa yang dipikirkan, harus dilakukan dengan upaya, usaha dan kerja keras. Untuk itu diperlukan sikap dan pandangan serta tindakan nyata oleh setiap individu dalam rumahtangga masyarakat nelayan. Namun yang dimaksud dengan tindakan yang mengarah pada perubahan dan perbaikan kondisi ekonomi adalah dengan mendirikan usaha dan mau mengembangkan usaha yang telah dibangun serta meciptakan usaha-usaha alternatif dalam meningkatan pendapatan masyarakat nelayan.

Guna meningkatkan pendapatan kelompok nelayan desa Bandengan Jepara, berbagai program telah disiapkan, seperti usaha alternatif berupa jasa penyebrangan dari pantai Prawehan menuju ke pulau Panjang, dimana perahu disiapkan dan di desain semenarik mungkin, agar wisatawan merasa nyaman. Disamping itu juga diadakannya pelatihan dalam mengelola hasil ikan menjadi produk siap saji.

Di era globalisasi saat ini, informasi bergerak dengan sangat cepat, penggunaan media internet melalui on line system membuka peluang bagi kelompok nelayan untuk dapat memasarkan produk olahan 
hasil lautnya untuk lebih dikenal lebih baik lagi oleh para wisatawan, baik wisatawan domestik maupun wisatawan asing. Untuk itu pelaku kelompok nelayan, dituntut menjadi bagian dari komunitas global dengan pemanfaatan teknologi informasi melalui media on line system.

On line system merupakan salah satu cara yang dapat dilakukan oleh pelaku kelompok nelayan, untuk dapat mengenalkan produk olahan ikan siap sajinya ke para wisatawan. Kelompok nelayan harus melihat manfaat On line system untuk akses informasi secara luas, mudah dan effisien. Kelompok nelayan dapat memperoleh manfaat serta keuntungan dengan menggunakan media On line. Hal ini dikarenakan, media On line dalam hal biaya jauh lebih murah dan effisien. Selain itu dengan menggunakan media on line, maka informasi dapat diakses tanpa batas. Saat sebuah informasi diinformasikan melalui media On Line system, maka informasi dapat diakses oleh pengunjung dari belahan dunia manapun selama didaerah tersebut memiliki akses internet.

Dan untuk peningkatan dalam berbahasa Inggris, kelompok nelayan diberikan pelatihan dengan metode "Bekerja Sambil Belajar". Metode ini memungkinkan kelompok nelayan tetap melakukan aktifitasnya sehari-hari dalam mencari ikan, dan dapat mempelajari bahasa Inggris dengan baik. Tim Pengabdian Masyarakat STIMART "AMNI" Semarang menyebar untuk memberikan pembelajaran bahasa Inggris tanpa mengganggu aktifitas nelayan dalam mencari nafkah. Dan sebagai alat pendukung pembelajaran bahasa Inggris, tiap kelompok nelayan mendapatkan buku Basic English for Fisherman yang telah disusun oleh Tim pelaksana Kegiatan Pengabdian masyarakat, guna mempermudah nelayan dalam memahami pembelajaran bahasa Inggris. 


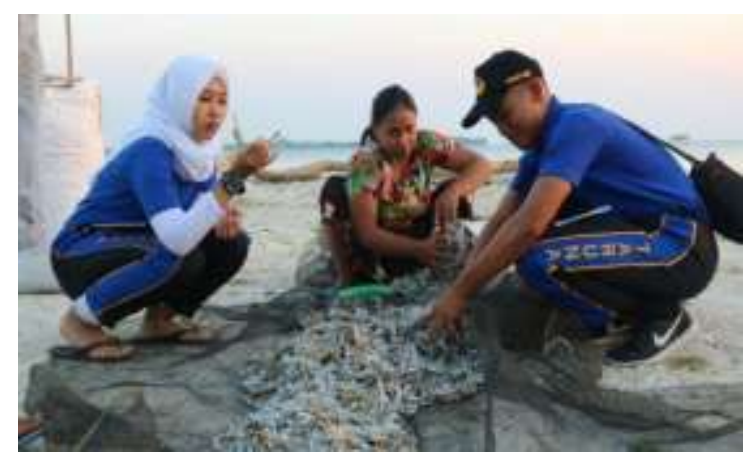

Gambar 5. Pembelajaran Bahasa Inggris dengan konsep "Belajar sambil Bekerja"

\section{METODE PENELITIAN}

Metode penelitian yang digunakan adalah metode observasi, wawancara dan studi literatur. Dimana observasi diadakan di pantai Prawehan desa Bandengan kecamatan Jepara kabupaten Jepara. Sedangkan pengumpulan data dilaksanakan melalui metode wawancara dengan kelompok nelayan desa Bandengan Jepara. Dan sebagai dasar acuan pelaksanaan kegiatan pengabdian masyarakat, menggunakan metode studi literatur.

Dalam pelaksanaannya di lapangan kegiatan pengabdian masyarakat didasarkan pada analisis situasi kelompok sasaran (masalah, potensi dan peluang), dimana setelah melaksanakan evaluasi terhadap kelompok nelayan, maka langkah selanjutnya adalah mencari solusi baru guna mendapatkan pemecahan masalah. Sementara evaluasi dan alternatif pemecahan masalah akan dilaksanakan setelah wawancara dengan kelompok nelayan selesai dilaksanakan. Untuk mencapai tujuan dari kegiatan yang telah ditetapkan diatas maka disusunlah beberapa kegiatan sebagai berikut :

a. Pemberian wacana pendapatan di luar hasil laut

Ketergantuang nelayan terhadap hasil tangkapan ikan di laut sangat tinggi, sehingga saat hasil tangkapan tidak sesuai dengan harapan, maka para nelayan tidak mendapatkan pendapatan untuk memenuhi kehidupannya sehari-hari. Untuk itu dibutuhkan alternatif pendapatan lain yang dapat dihasilkan, bila hasil tangkapan ikan tidak sesuai dengan harapan. Salah satu sumber pendapatan lain adalah dengan mengadakan jasa penyebrangan antara pantai Prawehan menuju ke pulau Panjang. Banyaknya wisatawan yang berkunjung ke pantai Prawehan, sangat tertarik untuk mengunjungi pulai Panjang, hal ini merupakan 
peluang usaha bagi para nelayan yang dapat dikerjakan saat para nelayan pulang melaut di pagi hari.

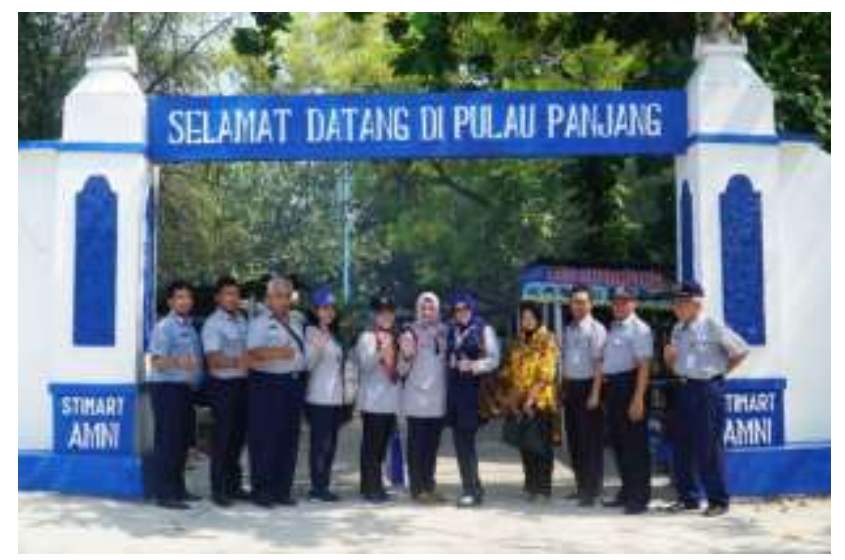

Gambar 5. Panorama di pulau Panjang

b. Pengolahan Hasil Laut menjadi produk jadi

Banyaknya hasil laut yang didapatkan oleh kelompok nelayan desa Bandengan Jepara, membawa masalah apabila hasil tangkapan ikan tidak semuanya terjual, dan ikan-ikan yang tidak terjual tersebut, membusuk dan akhirnya terbuang sia-sia. Hal ini bisa mendatangkan kerugian untuk para nelayan. Untuk itu dibutuhkan antisipasi agar hasil tangkapan ikan tidak terbuang secara sia-sia. Dari hasil tangkapan ikan yang tidak terjual, dapat langsung diolah menjadi olahan produk siap saji/siap dikonsumsi. Hasil olahan siap saji dapat berupa nagget ikan, abon ikan, keripik ikan, dan lain sebagainya.

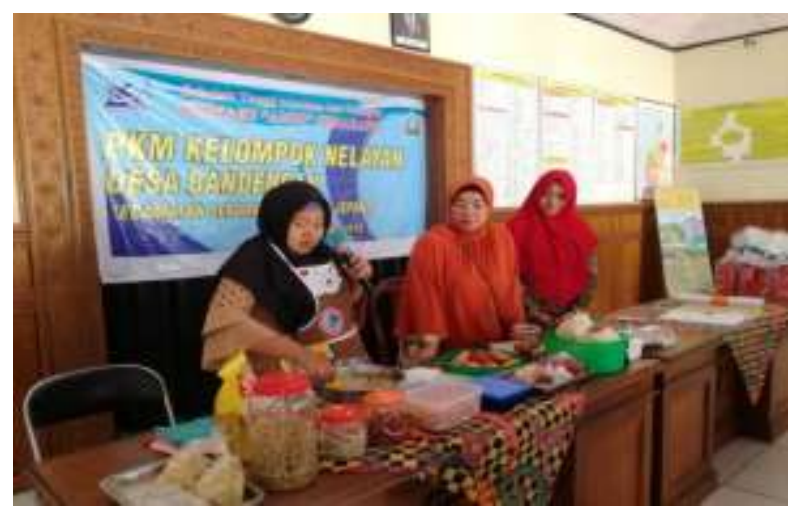


Gambar 6. Pelatihan hasil olahan ikan menjadi produk siap saji

c. Pemasaran Produk hasil laut melalui media On Line System

Hasil olahan ikan yang telah dibuat menjadi olahan siap saji sangat membutuhkan pemasaran sebagai media yang menjembatani antara kelompok nelayan dengan calon pembelinya. Untuk memudahkan pemasaran produknya, kelompok nelayan diberikan pelatihan, bagaimana memanfaatkan teknologi saat ini untuk mempermudah penyampaian informasi ke masyarakat, baik itu masyarakat di wilayah kota Jepara, maupun masyarakat luas di luar kota Jepara.

Tim Pengabdian masyarakat telah menyusun beberapa cara yang mudah untuk diikuti oleh para kelompok nelayan dalam memasarkan produknya. Yaitu dengan metode $O n$ Line System. Media yang digunakan bukanlah media yang sangat rumit, tetapi media yang sudah terbiasa diaplikasikan oleh masyarakat kelompok nelayan. Yaitu dengan menggunakan media sosial maupun media chat on line yang dapat digunakan untuk mengenalkan produk nelayan ke masyarakat luas.

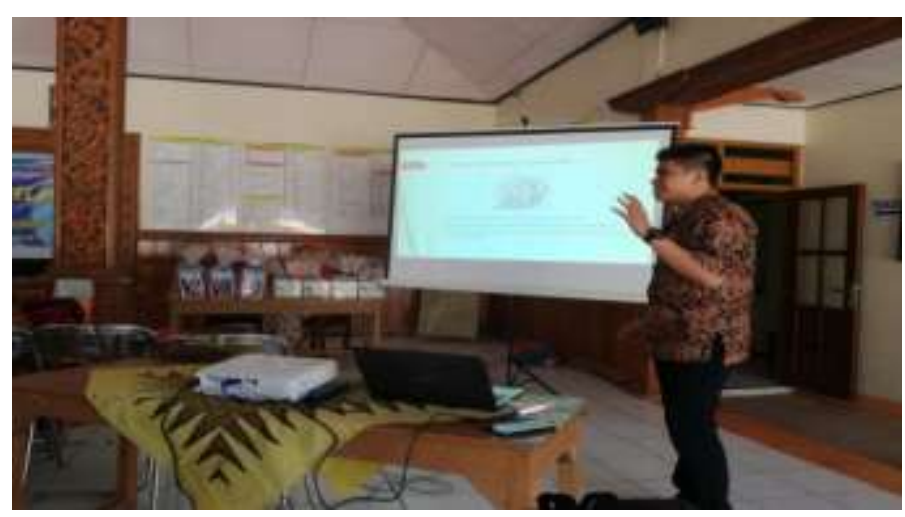

Gambar 7. Pelatihan memasarkan produk melalui media On Line System

d. Pembelajaran Bahasa Inggris dengan metode belajar sambil bekerja Dalam arti, kelompok nelayan tidak harus duduk di bangku seperti di ruang kelas, tetapi kelompok nelayan dapat melaksanakan aktivitasnya untuk bekerja seperti kegiatan yang mereka lakukan sehari-hari, dan Tim Pengabdian Masyarakat STIMART "AMNI" mendampingi para nelayan untuk belajar berbahasa inggris diselasela kegiatannya. 


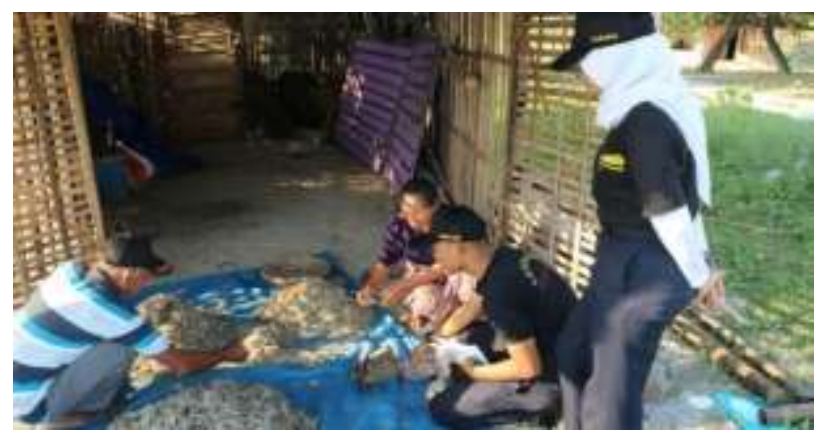

Gambar 8. Pembelajaran Bahasa Inggris dengan metode "Belajar sambil Bekerja"

\section{HASIL DAN PEMBAHASAN}

Guna mencapai tujuan dan sasaran pelaksanaan kegiatan pengabdian masyarakat, maka disusunlah rencana kegiatan yang meliputi beberapa pentahapan sebagai berikut :

\section{Tahap 1 : Persiapan}

Tahap persiapan dilaksanakan dengan mengadakan kunjungan awal (preliminary survey) untuk mendapatkan data awal kegiatan yang dibutuhkan di desa Bandengan Jepara. Dari data awal ditemukan bahwa mayoritas penduduk desa Bandengan Jepara memiliki kesulitan dalam berkomunikasi dengan wisatawan asing. Hal ini diakibatkan karena desa Bandengan memiliki pantai Prawehan yang merupakan potensi pariwisata di desa Bandengan. Dimana wisatawan yang datang tidak hanya wisatawan domestik, tetapi juga wisatawan asing. Untuk itu, dalam tapat persiapan kegiatan yang dilaksanakan adalah menetapkan rencana jadwal kerja, menetapkan pembagian kerja, menetapkan kelompok nelayan yang akan diberikan pelatihan kemampuan dalam berbahasa Inggris. Dalam tahap persiapan ini juga di temukan kenyataan bahwa banyak ikan yang busuk akibat hasil tangkapan yang meningkat tetapi tidak terjual habis di pasaran. Kegiatan dilanjutkan dengan survey lapangan untuk mencari data kelompok nelayan sebagai peserta pelatihan, dan untuk mendapatkan pendapatan tambahan, maka kelompok nelayan di berikan beberapa wacana yang dapat dilakukan 
untuk menutup kekurangan apabila hasil tangkapan tidak memenuhi kebutuhan sehari-hari, dan yang terakhir adalah melaksanakan koordinasi dengan Petinggi Desa Bandengan Jepara.

\section{Tahap 2 : Pelaksanaan}

Langkah selanjutnya adalah melaksanakan pemilihan peserta pelatihan, menentukan tim pendamping pelatihan pembelajaran bahasa Inggris, dan praktek pelatihan On line system. Sistematika pelaksanaan kegiatan pelatihan bahasa Inggris yaitu dengan melibatkan 10 taruna STIMART "AMNI" dari komunitas English Club yang akan mendampingi kelompok nelayan dalam pembelajaran bahasa Inggris. Dimana setiap taruna mendampingi 2-3 nelayan. Dalam pelaksanaannya Taruna di dampingi oleh beberapa dosen Bahas Inggris. Sedangkan untuk kegiatan pelatihan media on line, Kelompok nelayan langsung mendapatkan pelatihan dari Tim IT STIMART "AMNI" Semarang. Dan Tim Pengabdian masyarakat STIMART "AMNI" Semarang mendatangkan pelatih yang khusus untuk dapat mengolah hasil tangkapan ikan menjadi produk jadi dan siap di konsumsi.

Tahap 3 : Monitoring, Evaluasi dan Penyusunan Laporan

Kegiatan pada tahap ini bertujuan untuk memonitor keberhasilan program pembelajaran kelompok nelayan di Desa Bandengan, Kecamatan Jepara Kabupaten Jepara. Sebagai indikator dalam tahap ini adalah peningkatan kemampuan nelayan dalam bahasa Inggris serta kemampuan nelayan dalam meng-up load informasi secara On Line berkaitan dengan pemasaran produk hasil laut menjadi produk siap saji. Bertambah banyaknya jumlah wisatawan asing yang datang ke pantai Prawehan desa Bandengan, merupakan indikator selanjutnya dalam menilai keberhasilan program pelatihan pemasaran produk siap saji melalui media On line system. Dengan hasil ini diharapkan Kelompok nelayan lain yang ada disekitar kota Jepara dapat termotivasi untuk meningkatkan kemampuan mereka melalui peningkatan ketrampilan sebagaimana tersebut diatas. Pada 
tahap ini sekaligus juga dilakukan evaluasi atas pelaksanaan program, baik pada Tahap persiapan, pelaksanaan maupun monevnya sendiri. Dan

kegiatan akhir adalah menyusun laporan kegiatan.

\section{KESIMPULAN}

Dari serangkaian kegiatan pengabdian masyarakat yang dilaksanakan oleh Tim pengabdian masyarakat STIMART "AMNI" Semarang, dapat disimpulkan bahwa masyarakat desa Bandengan, khususnya kelompok nelayan desa Bandengan, sangat antusias dan bersemangat dalam pelaksanaan pelatihanpelatihan baik itu pelatihan bahasa Inggris, pelatihan pengolahan hasil laut dan pelatihan pemasaran on line system. Hal ini tercermin dengan banyaknya kelompok nelayan yang hadir dari awal hingga akhir pelaksana kegiatan pelatihan. Dari peserta yang hadir, banyak diantaranya yang sudah berusia lanjut, dan hal ini merupakan penyemangat tersendiri bagi nelayan yang berusia masih muda. Dan dalam pelaksanaan pelatihan pemasaran dengan media on line system, para nelayan merasa tidak mengalami

Dengan berakhirnya pelaksanaan kegiatan pelatihan, diharapkan masyarakat nelayan desa Bandengan lebih maju lagi dalam segala hal, baik dalam pengolahan hasil laut, penguasaan bahasa Inggris maupun pemasaran produk yang dihasilkan dengan menggunakan media $O n$ Line System. Dan secara tidak langsung, dengan semakin meningkatnya kemampuan masyarakat kelompok nelayan dalam berbahasa inggris, membuat banyak wisatawan yang tertarik untuk datang ke Jepara dalam hal ini ke pantai Prawehan desa Bandengan. Semakin banyaknya wisatawan yang datang secara tidak langsung akan banyak membuka peluang usaha dan peningkatan pendapatan daerah Jepara melalui sektor pariwisata.

\section{DAFTAR PUSTAKA}

A. Ridwan Siregar, (2010), Penggunaan Sistem dan Teknologi Informasi untuk Usaha Kecil dan Menengah, USU eresipository (2008).

Arif Rahmana, (2009), Peranan Teknologi Informasi dalam peningkatan daya saing Usaha Kecil Menengah, Seminar Nasional Aplikasi Teknologi Informasi.

Bangs, David H, (2008), Pedoman Langkah Awal Menjalankan Usaha, Jakarta, Erlangga.

Kusmuljono BS, Ketua Tim Koordinasi Keuangan Mikro Indonesia, UKM : Menggerakkan yang kecil, mengentaskan kemiskinan, Gatra, 2 Januari 2008. 
Nofia Farida, (2010), Obyek Wisata Pantai Tirto Samudra berpotensi meningkatkan Kehidupan Sosial Ekonomi Masyarakat
Sanim, B.,(2009), Usaha Kecil, Menengah dan Koperasi dalam Mewujudkan Sistem Ekonomi Kerakyatan Menanggulangi Krisis Nasional. MMA-IPB. Bogor.

Wahab Saleh, (2009). Managemen Pariwisata. Jakarta, Pradya Paramita 